\title{
PANCA SATYA TERSIRAT DALAM EPOS MAHABHARATA SEBAGAI PENDIDIKAN KARAKTER GENERASI HINDU
}

\author{
Oleh \\ Putu Ari Natih \\ Universitas Hindu Negeri I Gusti Bagus Sugriwa Denpasar \\ arinatih1509@gmail.com
}

\begin{abstract}
The epic Mahabharata is a story of heroism originating from the Hindu religious scriptures part of the Itihasa book which consists of 18 parwa. Of the eighteen parwa contain many ethical and moral teachings to be used as guidelines in character education today, because there is a lot of moral degradation which greatly affevts the character of a child. In this paper we will explore one of the teachings of panca satya through character plays which are told in several parwa sections. The teachings of the panca satya are teachings about loyality, honesty and based on truth, which consists of satya wecana which is loyal to word, satya mitra is loyal to friends, satya laksana isloyal to the actions that are done, satya hredaya is true to conscience, and satya semaya is true to promise. Of the five parts of the panca satya that are implied in the Mahabharata epic, it is very thick with character education that emphasizes honest, responsible, independent, religious, friendly, creative, curiosity, love of the country, hard work, respect for prestige, and social care. The purpose of this paper is to adopt the characters of several plays as contained in the educational curriculum which emphasizes 18 characters. This type of research is qualitative by using the story analysis method.
\end{abstract}

Key word: Panca Satya in Mahabarata, Character Education

\section{ABSTRAK}

Epos Mahabharata adalah cerita kepahlawanan yang bersumber dari kitab suci Agama Hindu bagian dari kitab Itihasa yang terdiri atas 18 Parwa. Dari kedelapan belas parwa tersebut mengandung banyak ajaran etika dan moralitas untuk dijadikan pedoman dalam pendidikan karakter zaman ini, pasalnya banyak terjadi degradasi moral yang sangat mempengaruhi karakter seorang anak. Dalam tulisan ini akan menggali salah satu ajaran etika yakni ajaran panca satya melalui lakon tokoh yang diceritakan dalam beberapa bagian parwa. Ajaran panca satya tersebut merupakan ajaran tentang kesetiaan, kejujuran dan berlandaskan kebenaran yang terdiri atas satya wecana yakni setia pada perkataan, satya mitra yakni setia terhadap teman, satya laksana yakni setia pada perbuatan yang dilakukan, satya hredaya yakni setia terhadap kata hati, dan satya semaya yakni setia terhadap janji. Dari kelima bagian panca satya yang tersirat dalam epos Mahabharata tersebut sangat kental akan pendidikan karakter yang menekankan pada karakter jujur, bertanggung jawab, mandiri, religius, bersahabat, kreatif, rasa ingin tahu, cinta tanah air, kerja keras, menghargai prestasi dan peduli sosial. Tujuan tulisan ini untuk mengadopsi karakater beberapa lakon sebagaimana yang termuat 
dalam kurikulum pendidikan yang menekankan pada 18 pendidikan karakter. Jenis penelitian ini yaitu kualitatif dengan menggunakan metode analisis cerita.

\section{Kata Kunci: Panca Satya dalam Mahabrata, Pendidikan Karakter}

\section{PENDAHULUAN}

Manusia adalah makhluk paling sempura karena memiliki idep (pikiran) yang merupakan Rajendriya yang dapat membantu manusia membedakan baik dan buruk sehingga dapat mengantarkan manusia ke jalan dharma. Namun pikiran juga dapat menjerumuskan kedalam hal-hal keterikatan keduniawian yang negatif. Seperti halnya yang terjadi akhir-akhir ini banyak masyarakat khususnya remaja memiliki moral dan etika yang merosot akibat dari pikiran yang selalu mengikuti kama (nafsu) yang negatif diantaranya bersikap acuh, berbohong dan mengabaikan ajaran tat tvam asi. Walaupun tidak seluruhnya, namun hal itu menjadi perhatian dunia terutama dalam dunia pendidikan. Hasilnya dalam dunia pendidikan membuat terobosan dengan mengimbangi pendidikan dalam ranah kognitif, psikomotorik serta afektif yang pada umumnya dikenal dengan sebutan pendidikan karakter. Pendidikan ini menekankan pada realisasi dari pendidikan agama dan budi pekerti, khususnya pada pendidikan agama Hindu yang sangat berperan membentuk etika dan moral peserta didik Hindu agar menjadi manusia yang memiliki etika dan berakhlak mulia.

Dalam etika agama Hindu terdapat dasardasar ajaran dalam menjalankan dharma itu, diantaranya yakni Tri kaya parisudha yang artinya tiga prilaku yang membuat orang memiliki pikiran (manacika), perkataan (wacika), dan perbuatan ( kayika) yang adiluhur. Serta Panca Yama Brata yang artinya lima perbuatan yang harus dikendalikan diantaranya tidak boleh membunuh baik itu menyakiti sekalipun (ahimsa), selalu menuntut ilmu agar senantiasa dapat dijadikan penerang dalam kegelapan (brahmacari), selalu setia dan berpijak dalam kebenaran (satya), dapat melepaskan diri dari sifat-sifat keduniawian dalam hal ini terfokus dalam pengendalian diri (awyawahara) dan tidak mengambil hak milik orang lain yang disebut dengan mencuri ((asteya). Dan dasa yama brata yang memiliki arti dan makna yang sama dengan panca yama brata, hanya saja yang membedakan yakni cakupan bagian dan pemaparannya lebih meluas yakni terdiri dari sepuluh bagian diantaranya tidak bersikap kejam atau adharma (anrsamsa), saling memaafkan yang merupakan jalan kedamaian (ksama), setia dan berpijak dalam kebenaran (satya), tidak membunuh tanpa bertanggung jawab (ahimsa), mengendalikan hawa nafsu yang terdapat disetiap insan kehidupan (dama), teguh dalam pendirian yang tidak tergoyahkan yang diibaratkan bagaikan air yang berada di atas daun talas yang teroyak angin namun tidak buyar atau pecah (arjawa), selalu menebar rasa empati dan welas asih serta menolong dengan tulus ikhlas (priti), berfikir diatas jalan kebenaran yang jernih dan suci (prasada), selalu menunjukkan sikap ramah, sopan dan santun terhadap sesama (madhurya), serta selalu lemah lembut baik prilaku maupun perbuatannya (mardawa).

Berdasarkan pemaparan dasar etika tersebut, hal yang menjadi topik pembahasan yakni bagian satya, karena satya merupakan suatu kebajikan yang berlandaskan pada kesetiaan dan kebenaran yang menghantarkan kepada kedamaian dan kebahagiaan. Hal ini dipaparakan dalam gubahan susastra menjadi syair yakni dalam Wirama Kusumawicitra juga menyebutkan karena perkataan yang terdapat dalam bagian satya ini yang dapat

Panca Satya Tersirat dalam Epos Mahabharata sebagai Pendidikan Karakter Generasi Hindu 
menyebabkan sesuatu hal terjadi, hal ini dilihat dari isi wirama sebagai berikut:

Waśita nimittanta manemu lakșmi

Waśita nimittanta pati kapangguh

Waśita nimittanta manemu duhka

Waśita nimittanta manemu mitra.

Artinya:

Karena perkataan yang keluar itu akan menentukan kita menemukan kebahagiaan, karena perkataan juga yang menyebabkan kematian, begitu juga karena perkataan itu dapat menyebabkan kesengsaraan, dan juga karena perkataan dapat mempertemukan kita dengan teman yang sejati. (Surada, 2006:176-177).

Selain itu juga disebutkan keutamaan satya yang mengandung makna etika kejujuran, kesetiaan dan kebenaran dan juga pengendalian pikiran dengan lima bagian yang disebut panca satya. Terdapat juga dalam kitab Sarasamuscaya 130 yaitu sebagai berikut:

Brāhmano wā manusayanamadityo

Wapi tejasām,

Çiro wā sarwagatrānām

Dharmanam satyamuttamam.

Artinya:

Kalau diantara manusia, Brahmana itu paling utama, diantara semua yang bersinar, matahari itu yang paling utama, diantara semua anggota badan, kepala itulah yang utama, jika mengenai dharma, maka satya yang mengatasi segala-galanya. (Pudja,1985:74). Jadi interpretasi makna dari satya merupakan suatu moral yang menjadi pedoman dalam bertingkah laku menjalankan ajaran dharma.

Demikian tulisan ini membahas tentang ajaran satya yang terkandung dalam ajaranajaran suci Veda melalui susastra-susastra Hindu lainnya yang disusun agar mudah dipahami oleh masyarakat Hindu melalui cerita seperti epos Mahabrata yang disusun oleh maharsi Vyasa dan merupakan salah satu bagian dari kitab Itihasa yang memiliki 18 parwa, diantara parwa-parwa tersebut tersisip wejangan dari Sri Krishna kepada Arjuna tentang ajaran filsafat yang amat tinggi ke dalam kitab Pancama Veda yang termasyur namanya kitab Bhagawadgita (RISTEKDIKTI, 2016:117). Dengan terselipnya nilai moral dan etika dalam kesusastraan yang adi luhung, tulisan ini berupaya menggali ajaran panca satya yang terkandung dalam cerita mahabharata agar masyarakat Hindu dapat mengimplementasikan ajaran panca satya yang kental akan pendidikan karakter ke dalam kehidupan sehari-hari sehingga memiliki etika baik dan dapat dikatakan generasi Hindu yang berkarakter luhur.

\section{PEMBAHASAN}

\subsection{Panca Satya dalam epos Mahabharata}

Mahabharata merupakan salah satu epos terbesar dalam Agama Hindu yang menjadi bagian dari buah hasil kesusastraan yang memiliki 18 parwa yang menceritakan tentang silsilah kerajaan Kuru hingga terjadinya peperangan antara Pandawa melawan Korawa yang tidak lain merupakan saudara. Dalam kisah tersebut terselip ajaran satya yang dipegang teguh oleh beberapa tokoh yang dilakoni. Satya yang merupakan ajaran tentang kesetiaan, kejujuran dan berlandaskan kebenaran terdiri dari lima bagian yang disebut panca satya diantaranya yakni Satya Wecana (berpegang teguh pada kejujuran atau perkataan yang akan membuat seseorang berada dalam keterpurukan maupun kebahagiaan), Satya Mitra (setia dan tidak menghianati teman), Satya Laksana (berpegang teguh pada dasar kebenaran untuk melakukan suatu tindakan), Satya Hredaya (dapat mengikuti kata hati atau pikiran yang berdasarkan pada dharma), dan Satya Semaya (setia dan dapat menepati janji yang telah dibuat). Berikut ini beberapa ulasan mengenai 
ajaran etika dan moralitas dalam ajaran panca satya yang tersirat dalam cerita Mahabharata:

\subsubsection{Satya Wacana}

Ajaran Satya ini menitik beratkan pada perkataan yang adiluhung yang tidak lain adalah sebuah kejujuran yang utama. Dalam Adi Parwa atau parwa pertama yang mengisahkan tentang silsilah kerajaan Kuru dalam epos Mahabarata penulis menitik beratkan pada kisah Radheya (Karna) yang merupakan anak pertama yang tidak diharapkan kehadirannya oleh seorang gadis kecil yang tidak lain adalah Kunthi, dan akhirnya takdir menentukan bahwa anak balia tersebut diasuh oleh seorang kusir kerajaan bernama Atiratha dengan istrinya Radha. Kelahiran Radheya pun dijadikan rahasia selama ia belum beranjak dewasa. Namun pada saat yang tepat akhirnya Radha mengungkapan hal yang sebenarnya terjadi terhadap anak kesayangannya. Dalam Subramaniam (2011:48-50) dikisahkan Radheya bangun dari tidurnya dan menceritakan mimpi-mimpi yang telah dialaminya.

"ibu sangat sering tidurku diganggu oleh sebuah mimpi, dimana aku melihat seorang wanita yang berbusana sutra dan berkerudung menangisiku seperti dia adalah seorang putri kerajaan dan aku bertanya padanya, namun wanita itu hilang dari mimpiku dan tiba aku terbangun ibu, aku selalu memikirkan bahwa aku tidak mau menjadi seorang kusir layaknya ayahku yang seharusnya akulah yang mewarisi keahlian ayahku. Mengapa bisa demikian ibu?". Radhapun menyuruh Radheya mendekat dan memuluknya seakan ia takut kehilangannya, ia pun berkata dengan jujur "anakku, waktunya telah tiba dan aku akan memberitahumu tentang cerita. Ini terjadi lima belas tahun yang lalu ketika ayahmu Atiratha melakukan tapa di sungai Gangga tiba-tiba matanya tefokus kepada sebuah kotak yang sangat antik dan indah mengapung dibawa arus sungai yang tenang dengan memancarkan cahaya bagaikan permata yang bersinar dipantulkan oleh cahaya matahari pagi, lalu ayahmu berenang dan mengambil kotak itu, tak terduga di dalam kotak itu terdapat bayi yang begitu tampan dan gagah layaknya seorang ksatrya sedang tertidur lelap karena nyanyian suara air Gangga. Begitulah pikiran ayahmu. Dengan kotak yang ada di tangan ia pun berenang ketepian dan berlari pulang. "Radha! Radha liahatlah aku membawa sesuatu yang akan membuat kita bahagia" ujar ayahmu. Ibupun tidak dapat mempercayai apa yang aku lihat, namun itu memang benar adanya aku melihat seorang bayi yang sangat tampan bagaikan matahari berkilau karena kundala dan kuvaca."

Radheya tertunduk mendengar kenyataan itu, namun Radha tetap memeluknya erat seperti pelukkan terakhir kali dan Radheya berkata

"aku tidak akan meninggalkan ibuku yang selama ini telah merawat dan mendidikku, walaupun aku mengetahui siapa ibuku yang sebenarnya kelak, karena ibu Radha adalah ibuku yang paling menyayangiku sepenuh hati."

Radheyapun memeluk ibunya, air mata mereka mengalir dan bersatu. Dari kutipan cerita adi parwa tersebut. Nilai moral dan etika yang dapat kita petik adalah kejujuran yang dilakukan oleh Radha walupun selama lima belas tahun telah memendam kebohongan, namun kebohongan itu diperbolehkan dalam ajaran agama Hindu yang disebut Panca Nrta salah satunya adalah berbohong kepada anak kecil yang belum dapat berpikir jernih demi keselamatan dan kelangsungan hidup seorang anak. Setelah

Panca Satya Tersirat dalam Epos Mahabharata sebagai Pendidikan Karakter Generasi Hindu 
waktunya tiba seorang anak sangup berpikir jernih dan menentukkan keputusannya sendiri maka kejujuran itu terungkapkan. Itulah salah satu karakter Hindu yang dipetik dalam kitab Bhagawadgita yang terkonsep kedalam pendidikan nasional di Indonesia. Nilai karakter yang dapat kita petik tersebut harus dijadikan pedoman hidup untuk selalu berkata jujur, terbuka dan apa adanya dengan melihat situasi kondisi dan tetap berada dijalan dharma yang utama. Selain nilai kejujuran adapula karakter anak Suputra yang patut ditiru yakni selalu hormat dan menyayangi orang tuanya walau bagaimanapun keadaannya.

\subsubsection{Satya Laksana}

Ajaran satya laksana mengajarkan setiap manusia harus bersikap yang baik serta bertanggung jawab. Hal itu dilihat dari kisah Mahabharata yang mengisahkan prilaku yang baik serta menghormati guru, seperti halnya Kunti yang diceritakan pada saat Rsi Durvasa datang ke kota Kuntibhoja dan menemui raja Kuntibhoja. Rsi tersebut terkenal akan tapa dan sikapnya yang tegas. Dalam Subramaniam (2011:24) mengisahkan tanggung jawab dan kedisiplinan seorang siswa kepada gurunya yakni tiada lain adalah Kunti yang telah diberikan kepercayaan oleh ayahnya untuk melayani sang Rsi yang merupakan suatu tugas yang sangat sulit. Namun Kunthi melakukan hal itu dengan penuh rasa hormat. Sang Rsi sangat senang dengan sikapnya dan pada hari terakhir Kunti diberikan anugrah sebuah mantra. Sang Rsi pun berkata tanpa penjelasan yang mendalam "mantra yang aku anugrahkan ini dapat memanggil Dewa yang kau pikirkan dan Dewa itupun akan datang padamu." Rsi Durvasapun pergi.

Kutipan cerita ini menggambarkan betapa bertanggung jawabnya gadis itu hingga dapat memecahkan tugas yang sangat sulit walupun orang yang dihadapinya bersikap tegas yang ditakuti dan disegani banyak orang namun Kunthi tetap berdasarkan pada prilaku yang sopan dan hormat. Hal itulah yang harus dijadikan cerminian dalam melakukan suatu kegiatan dan pekerjaan baik itu dalam bekerja maupun dalam menimba ilmu (brahmacari) harus didasarkan dengan karakter yang bertanggung jawab agar dapat menuntaskan dan memperoleh hasil yang baik.

Selain itu dalam parwa ini menceritakan juga tentang seorang murid yang sangat ideal yakni dapat berbakti dan berguru dengan pikirannya sendiri serta menjalankan bakti itu dengan penuh bersungguh-sungguh dan bertanggung jawab. Hal itu tidak lain dan tidak bukan adalah seorang anak Nisadha yang bernama Ekalavya yang berguru dengan patung yang dibuatnya. Dikisahkan dalam epos ini (Subramaniam, 2011:46) seorang anak keturunan Nisadha mendatangi Acarya Drona untuk meminta bimbingan dan ilmu dalam persenjataan, namun Drona berkata:

"Maaf anak muda, aku hanya mendidik dan mentransfer ilmuku pada anak kaum ksatriya saja, karena aku telah berjanjii untuk menjadikan Arjuna sebagai pemanah yang tidak dapat tertandingi". Namun hal itu tidak mematahkan semangat Ekalawya, ia pun pergi kehutan dan membuat patung Acraya Drona dari lumpur dan iapun memanggil patung itu sebagai sebutan guru dan belajar dengan giat. Dengan keinginannya yang begitu besar didorong dengan latihan yang keras menjadikan ia sebagai seorang pemanah yang hebat. suatu ketika Pandawa pergi ke hutan dan tanpa disengaja melihat ada seorang pemuda yang lebih hebat dalam hal memanah dari Arjuna dan mengaku sebagai murid Drona, hal itu dilaporkan kepada gurunya Drona dan merekapun pergi menemui Ekalawya yang tidak diketahui oleh Drona bahwa selama ini ia pernah bertemu dengannya. Akhirnya 
Ekalawya yang tidak mengetahui bahwa Drona akan dapat mencintainya, menceritkan bagaimana ia bisa menjadi murid Drona, dengan keluguannya itu Dronapun meminta Daksina yaitu dengan memetong ibu jarinya. Tanpa pikir panjang Ekalawya pun memberikan ibu jarinya dan mencium kaki gurunya dengan rasa hormat.

Berdasarkan kutipan cerita ini dapat dilihat dari kaca pendidikan era milenial yang menjunjung nilai kesetiaan terhadap apa yang dilakukan, dimana kurikulum menuntun karakter siswa seperti Kunthi yang bertanggung jawab dengan pengabdiannya dan Ekalawya yang lebih berperan aktif (mandiri) dalam proses pembelajaran serta menumbuhkan rasa ingin tahu, kreatif, mandiri, disiplin, bertanggungjawab dan kerja keras. Dengan belajar lebih giat sendiri siswa akan menemukan hal-hal baru sebagai pengalaman dan pengetahuan yang akan lebih cepat diingat. Selain itu etika yang dapat digali dalam proses brahmacari yakni sebagai seorang siswa harus selalu menghormati gurunya tanpa ada menyimpan rasa dendam dan menghargai prestasi yang telah diperoleh. Oleh karena itu, kutipan cerita tersebut diharapkan dapat dijadikan kontemplasi bagi generasi Hindu.

\subsubsection{Satya Hredaya}

Ajaran ini mengajarkan tentang kesetiaan mengikuti kata hati yang berlandaskan kebenaran. Dalam Virata Parwa (Subramaniam, 2011:194-300) bahwa Radheya bermimpi bertemu dengan Brahmana yang tidak lain merupakan Dewa Surya dan memberikan sebuah pesan.

"Wahai pemuda aku berpesan agar nanti saat pemujaan kamu selesai dan melakukan tugasmu seperti biasanya yakni memberkati seseorang yang meminta apapun darimu jangan kau berikan apa yang diminta oleh Dewa Indra nanti dan cobalah untuk menawar permintaan itu. Karena dewa Indra mengkehendaki Kuvaca dan Kundalamu, Dewa Indra bermaksud agar kau terkalahkan nanti oleh Arjuna, karena kekuatan dan tameng mu berada pada kuvaca mu dan antingantingmu adalah kundala mu, jikau kau berikan itu maka dapat dipastikan kematain akan menjemputmu dalam kekalahan nanti." Radheyapun tersentuh hatinya karena ada orang lain juga yang menyayanginya seperti ibu Radha. Namun Radheya dengan senyuman menjawab "engkau adalah saksi dari setiap pemujaanku, setelah pemujaanku berakhir aku harus menunggu seseorang meminta berkat dariku seperti yang telah aku lakukan biasanya, dan aku akan memberikan apapun yang diminta termasuk nyawaku menjadi taruhannya. Aku akan bahagia dan merasa terhormat jika dapat memberikan apa yang mereka perlukan, dan aku lebih baik mati dengan kemasyuranku yang mulia daripada aku harus hidup selamanya dengan hinaan." Setelah itu Radheyapun bangun dari mimpinya, dan siangpun menyinarinya, seperti yang telah diceritakan dalam mimpinya iapun kedatangan Dewa Indra saat melakukan pemujaan, dan benar ia pun memberi tanpa menolak apa yang diminta oleh Dewa Indra. Radheya yang dikenal dengan nama Karna akhirnya memotong anting dari telinganya serta mencabut kuvaca dan meletakan di atas mangkok Dewa Indra. Radheyapun bahagia karena telah mengorbankan hidupnya demi dharma. Hal itu membuat Dewa Indra beserta makhluk surgawi memberkati Radheya dengan rasa bangga.

Dari kutipan cerita ini dapat dipetik bahwa nilai moral Radheya ini mencerminkan anak yang berakhlak mulia, menuruti kata hati dan memiliki karakter religius yang tinggi karena 
selalu taat mengamalkan ajaran agama dan melaksanakan kewajiban persembahan dengan tulus ikhlas dan peduli sosial terhadap sesama dengan saling tolong menolong seperti halnya Radheya yang selalu memberikan pertolongan melalui permohonan seseorang dalam pemujaannya yang tak pernah diabaikan. Dari sikap Radheya (Karna) dalam kutipan tersebut dapat dijadikan cerminan untuk selalu menanamkan karakter religious dan peduli sosial bagi generasi Hindu.

\subsubsection{Satya Mitra}

Bagian awal epos Mahabarata yang disebut Adiparwa yakni parwa pertama diceritakan tentang persahabatan Radheya (Karna) terhadap Korawa yang sangat kuat karena rasa hormat dan hutang budi Karna kepada Duryodhana pada saat pertandingan adu keahlian itu. Dalam Subraniam (2011:61-113) pada saat pertunjukkan keahlian para pangeran Hastina yang tidak lain adalah para Pandawa dan Korawa, tiba-tiba datang seorang pemuda yang gagah berani dengan kuvaca dan kundala yang bernama Radheya (Karna) menantang keahlian Arjuna dalam hal perpanahan nmaun ia di tolak mentah-mentah oleh guru Drona dna Pandawa karena asal usulnya bukan berasal dari kerajaan melainkan seorang anak sutaputra dari seorang kusir kerajaan. Melihat kelihaian ilmu pemuda itu Duryodhanapun bangun dari tempat duduknya bagaikan ular kobra yang sudah siap mengeluarkan bisanya dengan memiliiki siasat untuk menjatuhkan Pandawa akhirnya Duryodhana menerima dan mengangkat derajat pemuda itu yakni dengan diberikan tahta kerajaan Angga dan berkata " anak muda, siapapun dirimu, sifatmu yang mulia itu berhak mendapatkan kekuasaan lebih besar dibandingkan dengan kerajaan kecil yang telah kuberikan ini, aku tidak menginginkan apapun dari pelayanan kecilku ini, aku hanya menginginkan persahabatan."
Radheyapun tersenyum dan memberikan hormat kepada Duryodhana. Tak hanya itu persahabatan mereka terbukti dalam untaian kalimat Radheya " aku tidak senang adanya persahabatan yang dibuat-buat dengan Pandawa, karena aku benar-benar berada dipihak Korawa dan akan berperang melawan Pandava.

Melalui kutipan cerita tersebut dapat kita petik nilai yang adiluhung, walupun mereka berada pada pihak adharma namun nilai persahabatan mereka dapat dijadikan pedoman. Selain kutipan tersebut terlihat juga nilai persahabatan yang diamalkan oleh pihak Pandawa.

Hal tersebut dapat dilihat dalam cerita bagian Vanaparva (Subramaniam, 2011:204) yang mengisahkan persahabatan Krsna dengan para Pandawa yang dilihat dari saat Krsna marah kepada Korava, dan Arjunalah yang menenangkan teman baiknya itu. Krshna pun berkata "Yudhistira wahai penegak Dharma, kehidupanmu dan kehidupanku terikat satu sama lain. Karena halnya Krisna ynag merupakan perwujudan Avatara Wisnu yang memiliki tujuan sederajat dengan dharma. Musuhmu adalah musuhku juga, dan aku tidak akan beristirahat jika aku belum menghancurkan musuh-musuhku bersama. Aku bersumpah untuk melakukan ini."

Hal itu diceritakan kembali pada saat peperangan terjadi yang menjadi dua belah pihak yakni Korawa dan Pandawa dan kedua belah pihak sama-sama mendukung para sahabatnya. Dalam cuplikan cerita ini dapat kita jadikan cerminan dan pedoman dalam menjalin persahabatan yang utuh tanpa adanya rasa berkhianat, begitupula dalam pendidikan karakter dihimbau agar dapat memiliki sikap kumunikatif dan proaktif atau senang bersahabat yang harus dimiliki oleh seorang generasi penerus bangsa serta 
memiliki rasa cinta tanah air seperti halnya Pandava yang selalu menegakkan kebenaran dalam merebut kekuasaan atas kerajaan agar menciptakan kemakmuran rakyat dan wilayahnya.

\subsubsection{Satya Semaya}

Ajaran satya semaya ini memfokuskan pada ajaran dan tingkah laku yang selalu setia pada janji yang telah diucapkan. Adiparva merupakan awal dari sebuah perjanjian yang sakral diucapkan antara Dewi Gangga dengan delapan Vasu yang melahirkan Devavrata. Dalam epos Mahabarata (Nurkancana, 2010:7-9) menceritakan tentang turunnya Dewi Gangga ke bumi karena ada seorang raja bernama Mahabisa.

Mahabisa adalah seorang manusia yang berkat yadnyanya dia berhasil masuk sorga. Ketika raja Mahabisa, para Dewa dan Dewi Gangga menghadap Dewa Brahma, saat perjalanan pakaian Dewi Gangga tersingkap, sebaliknya raja Mahabisa menikmati pemandangan tersebut dan Dewa Brahmana pun marah sehingga mengutuk Raja Mahabisa agar turun kedunia menjadi Raja Santanu, begitupun Dewi Gangga juga dikutuk turun ke dunia menjadi suami raja Mahabisa. Dia baru diperbolehkan kembali ke sorga setelah melahirkan delapan orang putra. Ketika dewi Gangga akan turun ke dunia, sang Dewi bertemu dengan delapan orang Vasu yang juga akan menjalani kutukan dengan menjelma sebagai manusia karena kedelapan orang Vasu itu telah mencuri lembu seorang Bhagawan yang bernama Rsi Wasista. Salah seorang Vasu itu bernama Prabata yang memiliki istri bernama Dewi Dyah yang memaksa suaminya untuk mencuri susu lembu tersebut agar dapat diberikan kepada sahabat istrinya agar hidup selamanya. Karena cintanya kepada istri, Prabata lalu mengajak saudara-saudaranya untuk mencuri lembu tersebut. Bhagawan Wasista menjadi marah lalu mengutuk para Vasu menjadi manusia. Para Wasu mengembalikan lembu dan meminta maaf kepada Bhagawan Wasita dan juga mohon agar kutukannya dicabut, Bhagawan Wasitapun dengan hati yang tulus memaafkan mereka tetapi kutukan yang sudah diucapkan tidak bisa dicabut hanya bisa diberikan keringanan yaitu meraka bisa langsung bebas segera setelah dilahirkan sebagai akibat mencuri, namun tidak dengan Prabata karena ia lebih berdosa karena mau menuruti kemauan istrinya, dalam penjelmaan menjadi manusia, Prabata akan hidup lama dan tidak beristri. Dari cerita tersebut dalam kedelapan kelahiran anaknya hanya Prabata lah yang diberikan hidup bersama ayahnya yakni Raja Santanu, lalu Dewi Gangga pergi meninggalkan putra dan suaminya kek Sorga.

Kutipan cerita tersebut dapat dipetik menjadi sebuah pedoman atas ketepatan janji Dewi Gangga terhadap kedelapan Vasu itu. Dalam hal ini tercermin sikap saling membantu orang lain disebut dengan sikap peduli sosial yang tersirat dalam pendidikan karakter. Selain itu dalam epos adi parwa ini juga menceritakan hal tentang janji dari Bhisma bahwa seorang ksatrya pewaris tahta kerajaan bersumpah untuk melajang seumur hidupnya dikarenakan rasa sayang yang amat mendalam serta rasa bhaktinya kepada Ayahandanya agar dapat membahagiakannya. Hal serupa juga disebutkan dalam artikel Wiguna (2018:9) yang berjudul Karakter Anak Suputra dalam Itihasa dan Puraana (Sebuah Kontemplasi) mengisahkan bahwa Bhisma memang ditakdirkan untuk tidak menikah seumur hidup karena kutukan dari Rsi Wasistha, namun ada nilai etika dan moralitas didalamnya, yakni tidak semua

Panca Satya Tersirat dalam Epos Mahabharata sebagai Pendidikan Karakter Generasi Hindu 
orang bisa melakukan hal tersebut, demikianlah kemuliaan Bhisma karena bhaktinya kepada sang ayah. Selain itu hal tersebut terungkap pula dalam tulisan artikel Wiguna (2018:3) yang berjudul Keutamaaan Siva Purana (Senjata Ampuh Penghancur Dosa) menjelaskan tentang kutipan ajaran Veda "Matru Devo Bhawa", "Pitra Devo Bhava." Hormati ibu sebagai Dewi agung dan hormati ayah sebagai Dewa agung. Bhakti Bhisma dan Keteguhan hatinya dapat terbukti dari penolakan-penolakannya.

Subramaniam (2011:18-20) diceritakan tentang janji yang dipegang teguh oleh Bhisma yang mengharuskan ia harus melakukan beberapa penolakan. Penolakan Bhisma yang pertama yakni penolakkannya terhadap Dewi Amba yang meminta pertanggungjawabannya karena Bhisma membawa 3 putri dari kerajaan Pancala yang bernama Amba, Ambika dan Ambalika, namun Bhisma belum mengetahui ternyata Amba telah memilih Salya sebagai suaminya hingga membawa mereka pulang ke Hastinapura, namun hal itu terungkap ketika amba telah berada di Hastinapura dengan kebijaksanaan Bhisma, iapun mengembalikan Amba ke pelukan Salya namun ternyata Salya menolak dengan alasan bahwa ia telah dimenangkan oleh musuh, iapun meminta Amba untuk menagih pertangggungjawaban kepada Bhisma karena sebagai seorang ksatrya yang telah memenangkan seorang putri harus menikahi putri tersebut, namun dalam parwa ini Bhisma menolak mentah-mentah karena janjinya itu.

Hal serupa juga dilakukan oleh Bhisma (Subramanian, 2011:20) untuk memegang teguh janjinya itu. Diceritakan pada saat Satyawati meminta Bhisma untuk menikahi Ambalika dan Ambika karena kedua anak Satyawati yaitu Citragada dan
Wicitrawirya telah meninggal, namun mereka belum dikaruniai seorang anak yang akan melanjutkan garis keturunan kerajaan Hastinapura. Bhismapun terkejut seorang ibu yang telah mengetahui sumpah nya itu meminta agar mengurungi janjinya demi untuk menikah, walaupun dengan bersikeras Setyawati memohon namun Bhisma tetap kokoh pada dharmanya dan pada pendiriannya itu. Akhirnya secercah solusi datang menghampiri Setyawati, iapun memutuskan untuk memanggil anaknya Bhagawan Vyasa untuk menikahi kedua menantunya itu hingga lahirlah Drstarasta, dan Pandu.

Berdasarkan cerita itulah dapat dijadikan pedoman dalam berkata bahkan dalam membuat janji agar senantiasa menepati katakata dan janji yang telah diikrarkan, karena dalam zaman milenial ini seseorang sangat susah untuk berpegang teguh atas kata-kata atau janji dharma yang diikrarkan tersebut karena sekali janji dharma itu diucapkan harus dipegang selamanya. Itu merupakan salah satu etika dalam pergaulan yang mencerminkan moral yang baik dan diharapkan dapat dijadikan pedoman generasi muda dalam menanamkan karakter jujur dan menepati janji yang telah diucapkan agar dapat menjadi pribadi yang dapat dipercaya dalam melaksanakan suatu kewajiban.

\section{PENUTUP}

Mahabharata merupakan salah satu epos terbesar dalam Agama Hindu yang menjadi bagian dari buah hasil kesusastraan yang memiliki 18 parwa yang menceritakan tentang silsilah kerajaan kuru hingga terjadinya peperangan antara Pandawa melawan Korawa yang tidak lain merupakan saudara. Dalam kisah tersebut terselip ajaran satya yang dipegang teguh oleh beberapa tokoh yang dilakoni. Satya yang merupakan ajaran tentang kesetiaan, kejujuran dan 
berlandaskan kebenaran terdiri dari lima bagian yang disebut panca satya yang sangat kental akan pendidikan karakter. Melalui ajaran panca satya yang digali dalam epos tersebut, tersirat karakter jujur dalam satya wecana dan satya hredaya, karakter bertanggung jawab, mandiri, rasa ingin tahu, kreatif, disiplin, kerja keras, dan menghargai prestasi dalam satya laksana, karakter religius dan peduli sosial dalam satya hredaya dan karakter bersahabat serta cinta tanah air dalam satya mitra. Karakter yang digambarakan dari cerita tersebut dapat dijadikan sebagai kontemplasi untuk membangun karakter anak sebagaimana yang terkonsep dalam kurikulum pendidikan dengan menekankan pada pendidikan karakter yang terdiri atas 18 karakter.

\section{DAFTAR PUSTAKA}

Kementrian Riset, Teknologi dan Pendidikan Tinggi Republik Indonesia. 2016. Pendidikan Agama Hindu untuk Perguruan Tinggi. Jakarta: Direktorat Jenderal dan Kemahasiswaan.

Nurkancana, Wayan. 2010. Keutamaan Mahabharata. Denpasar: PT Pustaka Manikgeni

Pudja, Made. 1985. SARASAMUSCAYA. Jakarta:Depertemen Agama RI Dirjen Bimas Hindu dan Buddha.

Subramaniam, Kamala. 2011. $M A H \overline{A B} H \bar{A} R A T A$. Surabaya: Paramita

Surada, I Made. 2006. DHARMAGITĀ. Surabaya: Paramita

Wiguna, I.M.A. 2018. Karakter Anak Suputra dalam Itihasa dan Puraana (Sebuah Kontemplasi)

Wiguna, I. M. A. (2018). KEUTAMAAN SIVA PURAANA (Senjata Ampuh Penghancur Dosa). 